\title{
Education 4.0: The Effectiveness of VARK Learning Style towards Actualising Industrial Revolution 4.o
}

\author{
Shahrul Mizan bin Ismail \\ Associate Professor, Ph.D, Faculty of Law, \\ National University of Malaysia, UKM, \\ Bangi, Selangor, Malaysia \\ Wan Amir Azlan Wan Haniff \\ Ph.D Student, Faculty of Law, \\ National University of Malaysia, UKM, \\ Bangi, Selangor, Malaysia \\ Corresponding Author
}

Doi: 10.36941/jesr-2020-0045

Abstract

While Industrial Revolution 4.0 is a name given to the current trend of automation and data exchange in manufacturing technologies which includes cyber-physical systems, the internet, cloud computing and cognitive computing, Education 4.0 is a response to the needs of it where human and technology are coordinating together to empower new opportunities. This article examines the parties affected by Industrial Revolution 4.0 in relation to preparation needed for them to survive, with reference to Malaysia perspective. Moving forward, this article analyses whether VARK learning style is an appropriate model to measure skills and competencies of learners in an effort to match of what Industrial Revolution 4.o has to offer. This qualitative research utilizes secondary data gained from scientific database analysis and library research including documents on Industrial Revolution 4.0, Education 4.o E VARK model. These data were analysed. The study reveals that employees $\mathcal{E}$ administrators, generation $\mathrm{z}$ as well as educators are relevant learners in the preparation of Industrial Revolution 4.o. Further, VARK learning style is proven ineffective due to imperfect research on such model, combined with the hurdles to implement it in real-life situation and subject to mistakes and oversights in their judgement. This article concludes by stressing the need for policymaker to explore new teaching strategies and evaluate their effectiveness to ensure the learners are prepared to embrace changes and reduce a potential threat of technological unemployment.

Keywords: Employees, Students, Educators, VARK, Malaysia, Education 4.o

\section{Introduction}

To figure out the meaning of Education 4.o, it is crucial to first understand what does it mean by Industrial Revolution 4.o. Schwab (2016) lists down the stages of Industrial Revolution from the beginning to assist on how such revolutions changed across time. During the first Industrial Revolution, there were introduction of steam and water power to mechanize production while for second Industrial Revolution, there were mass production assembly lines using electrical power. 
During the third Industrial Revolution, information technology and electronics were used to automate production. Today, the world experiencing fourth Industrial Revolution (Industrial Revolution 4.o) where the advancement of new technologies blurs the lines between physical, digital and biological worlds (Anealka, 2018). Schwab (2016) and Schwab \& Davis (2018) agrees with Anealka (2018) and asserts that Industrial Revolution 4.0 bring these systems together.

Further, Hermann (2016) believes that Industrial Revolution 4.0 is a name specified to the ongoing trend of automation and exchange of information in production technologies which comprises the internet, cyber-physical systems, cognitive and cloud-based computing. The progresses are headed by the development of artificial intelligence, robotic process automation, the internet of things, autonomous vehicles and etc (Sosik \& Zhu, 2020). These modern technologies develop rapidly and disrupting almost every industry, thus being named as disruptive technologies (Diwan, 2017).

The article aims to examine parties affected by Industrial Revolution 4.0 in relation to preparation needed for them to survive, with reference to Malaysia perspective. Moving forward, this article analyses whether Visual, Auditory, Reading/writing, and Kinesthetic (VARK) learning style is an appropriate model to measure skills and competencies of learners in an effort to match of what Industrial Revolution 4.o has to offer. Hence, this article first elaborates the meaning of Education 4.o, followed by types of relevant learners before going further on the effectiveness of VARK learning style towards actualising Industrial Revolution 4.0.

\subsection{Education 4.0}

Anealka Aziz (2018) indicates that Education 4.0 is a response to the needs of Industrial Revolution 4.o where human and technology are coordinating together to empower new opportunities. Ahmad Arifuddin et al (2019) agrees and further adds that Education 4.0 deals with the prevalence of technologies and the problems created by information excess and also supports the notion that today's learners need to be trained and not simply taught by memorization and remembrance drills. To put it all together, the aspiration of Education 4.0 is to educate ourselves on how to prosper in a transforming world. In that regard, innovation, creativity, imagination, critical thinking to solve complicated and abstract problems become civically engaged in education concerns (Maria et al, 2020). Similar to Industrial Revolution 4.o, education revolution could be classified based on the level it has been emerged in the past centuries as shown in Table 1 below (Meylinda Maria \& Faaizah Shahbodin, 2018).

Table 1.o: Education 1.0 to 4.0 Comparison

\begin{tabular}{lll}
\hline Education Revolution & Methods & Technology \\
\hline Education 1.0 & $\bullet$ Dictation & $\bullet$ Not allowed during education process \\
& $\bullet$ Instructivism & \\
& $\bullet$ Direct transfer of information & \\
\hline Education 2.0 & $\bullet$ Progressivism & $\bullet$ Limited access \\
& $\bullet$ Begins to open to internet access & \\
\hline Education 3.0 & $\bullet$ Knowledge producing & $\bullet$ Full access for knowledge \\
& $\bullet$ Co-constructivism & $\bullet$ Construction and transmission \\
\hline Education 4.0 & $\bullet$ Innovation producing & $\bullet$ Always changing \\
& $\bullet$ Replacing classrooms & $\bullet$ Leaners as major source technology evolution \\
\hline
\end{tabular}

Fisk (2017) elaborates that modern insight of learning requires students to not merely expert on skills and knowledge that are essential for their future, but to also analyse the origin to study these abilities and information. In other words, learning is constructed in their surroundings in regards to how and where to learn and tracing of their performance is done through data-based customization. For instance, given the internet facilities which is made accessible and available $24 / 7$, learners able to 
learn on how to seek knowledge instead of to know things from their teacher's textbooks (Ahmad Arifuddin, 2019).

For Malaysia perspective, in the Education 4.0 framework, challenges of the Industrial Revolution 4.o are recognised in Malaysia Education Blueprint for Higher Education 2015- 2025. The aim of this blueprint is to ensure Malaysia's education system is in align with global trends with the focus to restructure the higher education system in Malaysia which features the harmony between both ethics \& morality along with knowledge \& skills (Malaysia Education Blueprint for Higher Education 2015- 2025, nd). Hence, the latter demands students to equip themselves with Information and Communication Technologies and collaborative skills as well as be engrossed in lifelong learning which are essential for them in coping with current revolution. This however could not be achieved if the students unable to develop the ability to think critically and creatively or if they have poor communicative skills (Rozana Sani, 2018).

\section{Parties Affected by Industrial Revolution 4.o}

The researcher believes that there are three (3) types of people who are most affected by Industrial Revolution 4.o. These people are existing employee \& administrators in economic sector, generation z and educators. They are the parties who must prepare and equip themselves with necessary knowledges so they will be able to meet challenges Industrial Revolution 4.0 brought. Educators for instance play a big role as they are the ones who will provide necessary knowledge to their students. Certainly, educators cannot educate without learning it first.

\subsection{Employees and administrators}

It is worth mentioning that enormous employee in different economic sectors are losing jobs faster than society can create them. This happen due to the prevalence of robotics, artificial intelligence, ${ }_{3} \mathrm{D}$ printing and other innovations that take over their occupation. A Hariharasudan \& Sebastian Kot (2018) emphasises that the most crucial challenges while enforcing Industrial Revolution 4.0 are found among the employees \& administrators, which suggests that these are the types of learners who are required to equip themselves with necessary skills. Nonetheless, most employees are lack of digital culture \& training as well as clear vision or support from managers Slusarczyk (2018). To add insult to injury, concurrently, the administrators also unclear on the economic benefits from investments in digital technologies and falsely believe in high financial investment requirements to recruit \& develop new talent, thus resulting difficulty for the company to keep up with the revolution. Wierzbicka (2018) adds that, since the impacts of Industrial Revolution 4.0 can be seen in our day-today lives, so it is reflected in all fields. Thus, it is paramount for each individual to observe every changes that is happening surrounding them and always keep learning new skills so they will not be left behind.

With the reform in work environment and tools to be used, the skills required need to evolve as well. According to Maria et al (2020), in order to face continuous transformation of economic, social and environmental landscape of Industrial Revolution 4.0, there is a vital need for individuals to think across disciplines. For example, automation, digitization and the rise in data volumes will require employees with a new set of skills which focussed on collaboration, data analytics and computer proficiency. Therefore, the present researcher believes that the interdisciplinary and multidisciplinary studies should be practiced as it will be useful tools to adapt with increasingly dynamic and complex world.

\subsection{Generation Z}

While there is a concern on the competency of existing employees and administrators in dealing with new revolution, there is a need to draw attention on the Generation $\mathrm{Z}$ (born in and after 20oos) who 
are currently studying or the senior ones are pursuing tertiary education (Oral, 2013). They will flood the workplace by the year of 2022 and acclimate changes in line with Industrial Revolution 4.o. As mentioned above, towards meeting the demands of the Industrial Revolution 4.o, the job market has become increasingly challenging, and unfortunately for them, the systems of current education are based on models designed to output a workforce for jobs that no longer exist, which is inadequate to meet the challenges ahead. Therefore, the policymakers at the top of the education field carries the burden to ensure the policy introduced is align with the current trend in Education 4.o. This is crucial especially in Malaysia where the unemployment rate in December 2019 increased in 3.3 per cent as compared to 3.2 per cent in November 2019. During this month, the number of unemployed accounted for 519.0 thousand persons, increased 0.6 per cent as compared to previous month (Malaysia Department of Statistics, 2020).

It is worth to emphasize that the workplace requires those who are equipped with multidisciplinary knowledge. This is among the reason why the National University of Malaysia offers their student interdisciplinary courses under program named CITRA (Sophisticated, Integration, Technology, Across Discipline Application). Through CITRA, students are given opportunity to take courses that are not in their field of study (Citra, nd). Not only that, CITRA also offers Bachelor of Science in liberal Studies (BSLS) course (Citra, nd). This course offers a Future-Focused Curriculum \& flexible and cross-disciplinary structured programs to the students so they will be able to build /create their own field of concentration relevant to their careers and personal goals. In this course, the delivery mode of 2 uzi mode ( 2 years in the university and 2 years in the industry) was applied. The zuzi mode focuses on work-based learning to improve graduate employability. Figure 1.o below shows the delivery mode of zuzi.

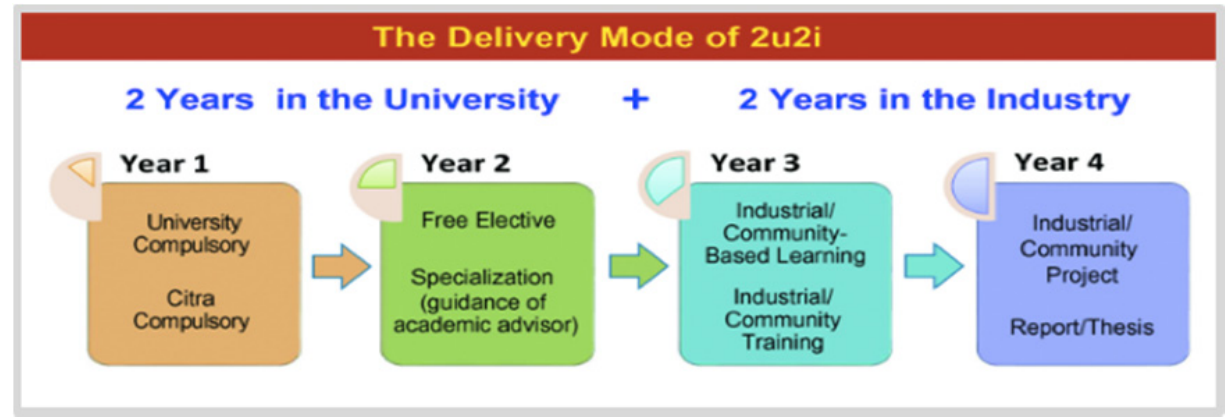

Figure 1.o: The Delivery Mode of zuzi

\subsection{Educators}

Adnan (2018) points out the need for tertiary curriculum to be compatible and innovative, both at technological and personal levels in order to realize the vision of Industrial Revolution 4.o. Doucet et al (2018) further adds that there is a need to bring technological developments from different courses into lecture rooms while taking into consideration the learning desires of the current generation because what was practical decades ago might no longer germane today (Adnan \& Zamzari, 2012a, 2012b). In simple words, the younger generation, especially Generation $\mathrm{Z}$ was born into technology and they need technology to make sense of the world.

For Malaysia perspective, several programs are introduced by Ministry of Education such as Massive Open Online Courses (MOOC) and CEO @ faculty. While the former will be the tools used in the future learning where the usage of textbooks will be reduced in the class, the latter is hoped to give awareness to academic practitioners and lecturers on new trends in the industrial field so they will understand well on how industrial field works. Reward will also be given to the educators who 
implement the best innovative style of teaching (Ministry of Education, nd). Undoubtedly, numerous learning styles could be utilised, but for the purpose of this research, VARK model is chosen and the rationales are stated below.

\section{Vark Learning Styles}

Lawal Ibrahim \& Punnarumol (2020) describes learning style as format in which an individual learn to receive, processes, and stores information in most favorable way. The style is said to conform with the personality of an individual, which can be influenced by environment factor. In tertiary education settings, there are high opportunity to enhance students learning performance through suitable learning style. This is essential to students since they are the ones who will embrace changes on what Industrial Revolution 4.o has to offer.

VARK model for instance was created by an educator named Dr. Neil Fleming in 1987. VARK refers to Visual, Auditory, Reading/Writing and Kinesthetic. Since the model can be carried out in various settings, which may include classroom, laboratories and clinical environmental settings, the model is said to be dynamic. Plus, it is straightforward instrument for students to utilise and understand so they will be able to create awareness of learning styles and provides motivation to seek improvements in their learning performance.

\subsection{Types of learners according to VARK model}

The VARK model classifies students in accordance with the sensory modality on how they choose to have information submitted to them (Fleming and Mills, 1992). For those who do not know which type they are belong, they can answer VARK questionnaire which is freely available online (VARK, 2017). The questions consists of 16 questions and the result represent which type among four VARK they truly are. The individual classification are:

1. Visual (V): If the individuals choose to view or study information by looking at pictures, flowcharts, drawings, maps or diagrams, they are categorised as a visual learners (Murphy et al. 2004). These individuals often considered as loud thinkers, have a high ability to recall visual procedures and usually use visual movements such as hand movements. Besides, Piping (2005) views students that have visual intelligence as imaginative and creative.

2. Auditory (A): If the individuals choose to hear information being presented to them and prefer repetition of words from discussions and lectures, they are classified as auditory learners. These individuals are advised to attend classes to listen to their lecturer, conversing the material with the rest as well as reading topic or notes aloud into a record player (Abbas Pourhossein, 2012). These individuals have a high ability for the aural recollection and usually learn with their heads up and use their eye actions when recalling information (Ldpride,n.d.).

3. Reading/Writing ( $R$ ): If the individuals choose to look at new information in writing via text or tables, they are classified as reading/writing $(\mathrm{R})$ learners. It is preferable for them to learn by writing down notes based on their own interpretations or arranging lists and information tables because their learning process depends on the written word (Drago and Wagner, 2004). Obviously, reading/writing style is the most commonly applied by conventional teachers in traditional learning settings. This type of learner is usually utilising textbooks, hand-outs and circulation as a favourite tool to collect data and share information (Naseer Ahmad, 2020).

4. Kinesthetic (K): Norasmah Othman \& Mohd Hasril (2010) describes kinesthetic (K) learners as individuals who learn by going through practice and experience. Since they rely significantly on contacts, touch and interaction to their environment within educational setting, specifically with their bodies or physical actions, it is suggested for them to learn by using real-life experience of a physical activity (Armstrong, 2004). 
It is worth highlighting that the learner is considered as unimodal if the learner has a preference for one (1) of these categories. While bimodal is refer to the learner who has preferences for two (2) categories, trimodal is for an individual who has preferences for three (3) categories. However, there is situation where a learner show preference for all four (4) categories. This individual is categorized as quadrimodal.

\subsection{Learning Styles based on VARK Model}

According to Nabiollah Sadeghi et al (2012), learners step into learning process with their own specialness including their own learning styles, approaches and character varieties. Alkhasawneh et al (2008) suggests that if educator furnishes different learning activities based on VARK model, students will be able to learn productively. They further mentions that there is a need to improve active learning by presenting models and demonstrations, debates, games, collaborative testing, manipulating models and role playing in large classrooms.

Despite the traction VARK model can offer in mainstream education, there are multiple challenges that comes with it, resulting to possible incompatibility for students to match their skills and competencies towards Industrial Revolution 4.0. Firstly, Hawk and Shah (2007) stipulates that the questionnaire itself is problematic as it is lack of demonstrated validity measures which made hard to indicate since the questions posed to the participants give no restrain or limit to a single answer. Leite et al. (2010) further adds that VARK model only suits for low stakes evaluations and not suitable for investigation since the efficacy of the content, response process, linkages between variables as well as implications of testing have still not been evaluated.

Secondly, it is clear that technology falls into the Kinesthetic category, whereby students learn by experiencing. This includes but not limited to simulations, real-life scenarios, case studies and group presentations (using office). Apart from that, since technology able to provide pictures, flowcharts, drawings, maps and diagrams, hence, technology is also part of Visual domain as well. Nevertheless, the research done by Rania \& Esra (2020) has found out that even though the use of a diversity of learning styles in class and during assessments encourage students to be more participative in learning activities, one must consider real-life situation in saturated classrooms, with no support provided from teaching assistants. In other words, educators usually do not have sufficient time to accommodate different exercises in their classes, rendering them dull and tiresome. Not to mention, Husmann and Dean (2018) believes that students continue to use VARK learning styles as a "crutch" for why they might not learn something well (e.g., "I'm just not a kinesthetic learner."). As a result, the integration of technology in learning process may not be achieved, thus resulting students to unable to polish their skills and competencies in technology which is material in Industrial Revolution 4.o.

Finally, there is high possibility that VARK model is subjected to mistakes and oversights judgement. A research has been done by Husmann \& Dean (2018) to determine whether undergraduate students are more likely to utilize study strategies that align with their VARK model. The finding shows that the alignment of these study strategies with VARK results had no correlation with course outcomes. Bjork and Bjork (2014) opines that this is happening because the students already have their own convenient approach of learning and it is difficult for them to venture into new style of learning.

\section{Conclusion}

Certainly, changes are inevitable. While the abovementioned learners become critical parties that are affected by Industrial Revolution 4.o, findings suggest that VARK learning style may not be effective model to be utilised in facing continuous transformations on the economic, social and environmental landscape of Industrial Revolution 4.0. Therefore, there is urgent call for policymaker to explore new teaching strategies and evaluate their effectiveness to ensure the learners are prepared to embrace changes and ultimately reduce a potential threat of technological unemployment. 


\section{Acknowledgement}

The author would like to thank and acknowledge that this research is funded by Centre for Research and Instrumentation Management (CRIM) UKM under Fundamental Research Grant Scheme (FRGS) no. FRGS-APRS/1/2017/SSI10/UKM/o2/1.

\section{References}

A. Hariharasudan \& Sebastian Kot. (2018). A Scoping Review on Digital English and Education 4.o for Industry 4.o. Social Sciences. 7(11): 227.

Abbas Pourhossein. (2012). Visual, Auditory, Kinaesthetic Learning Styles and Their Impacts on English Language Teaching. Journal of Studies in Education. 2(1): 104-113.

Adnan, A. H. M. (2018). Industry 4.0 skill sets, higher-order thinking skills and gamification: Lessons from 'Potentia Project', Malaysia (Plenary Panel Presentation). Proceedings from TING X 2018: The Tenth National Meeting of Teachers (Temu Ilmiah Nasional Guru) 'Innovation in Education for Indonesia 4.0'. Tangerang: Universitas Terbuka Indonesia.

Adnan, A. H. M., \& Zamari, Z. M. (2012a).“I am a Techno-Rebel!” Malaysian Academics \& their Personal Experiences of Progressing into e-Learning. Procedia-Social and Behavioral Sciences, 67:61-72.

Adnan, A. H. M., \& Zamari, Z. M. (2012b). Computer-Aided Self-Access Language Learning: Views of Indonesian, Malaysian \& New Zealand Practitioners. Procedia-Social and Behavioral Sciences, 67:49-60.

Ahmad Arifuddin, et al. (2019). Education 4.o Immersive Learning with Spherical Videos $\left(360^{\circ}\right)$ and Virtual Reality (VR) Experiences. In MNNF Network (Ed.), Proceedings: International Invention, Innovative $\mathcal{E}$ Creative (InIIC) Conference, Series 2/2019 (pp. 52-60). Senawang: MNNF Network.

Alkhasawneh, I. M., Mrayyan, M. T., Docherty, C., Alashram, S., \& Yousef, H. Y. (2008). Problem-based learning (PBL): Assessing students' learning preferences using vark. Nurse Education Today. 28(5):572-579.

Anealka Aziz Hussin. (2018). Education 4.o Made Simple: Ideas For Teaching. International Journal of Education \& Literacy Studies. 6(3): 92-98.

Armstrong, A. M. (2004). Instructional Design in the Real World: A View from the Trenches. United States: Information Science Publishing.

Bjork RA, Bjork EL. (2014). Making things hard on yourself, but in a good way: Creating desirable difficulties to enhance learning. In: Gernsbacher MA, Pomerantz JR (Editors). Psychology and the Real World: Essays Illustrating Fundamental Contributions to Society. 2nd Ed. New York, NY: Worth Publishers. p 59-69.

Citra. N.d. Taklimat Citra. http://www.ukm.my/pkp/wp-content/uploads/2015/o2/CITRA-20152016-PKP290915.pdf [8 March 2020].

Diwan, P. (2017). Is Education 4.0 an imperative for success of 4th Industrial Revolution? https://medium.com/@pdiwan/is-education-4-o-an-imperative-for-success-of-4th-industrial-revolution50c31451e8a4 [8 March 2020].

Doucet, A., Evers, J., Guerra, E., Lopez, N., Soskil, M., \& Timmers, K. (2018). Teaching in the Fourth Industrial Revolution: Standing at the Precipice. Oxford: Routledge

Drago, W. A., \& Wagner, R. J. (2004). VARK preferred learning styles and online education. Management Research News, 27(7): 1-13.

Flemming \& Mills. (1992). Not another inventory, rather a catalyst for reflection. To Improve the Academy, 11(1):137-155.

Hawk and Shah. (2007). Using learning style instruments to enhance student learning. Decision Sciences Journal of Innovative Education, 5(1):1-19.

Hermann. (2016). Design Principles for Industrie 4.0 Scenarios: A Literature Review. https://www.researchgate.net/publication/307864150_Design_Principles_for_Industrie_40_Scenarios_A_Lit erature_Review [8 March 2020].

Husmann, P \& Dean,V. (2018). Another nail in the coffin for learning styles? Disparities among undergraduate anatomy students' study strategies, class performance, and reported VARK learning styles. Anatomical Sciences Education. 12(1):6-19.

Lawal Ibrahim \& Punnarumol. (2020). VARK Learning Style Classification Using Decision Tree with Physiological Signals. Wireless Personal Communications. https://doi.org/10.1007/s11277-020-07196-3 [8 March 2020].

LdPride. N.d. What are learning styles? Retrieved from http://www.ldpride.net/learningstyles.MI.htm. [6 April 2020]. 
Leite WL, Svinicki M, Shi Y. (2010). Attempted validation of the scores of the VARK: Learning styles inventory with multitrait-multimethod confirmatory factor analysis models. Educ Psychol Meas 7o(2):323-339.

Malaysia Department of Statistic. (2020). Key statistics of labour force in Malaysia, December 2019. https://www.dosm.gov.my/vi/index.php?r=column/cthemeByCat\&cat=124\&bul_id=ZUgwOVBWSThiMXNK cod5SDBSS1Yidzog\&menu_id=U3VPMldoYUxzVzFaYmNkWXZteGduZzo9 [8 March 2020].

Malaysia Education Blueprint for Higher Education, 2015- 2025. N.d. https://www.um.edu.my/docs/ummagazine/4-executive-summary-pppm-2015-2025.pdf (8 March 2020].

Maria, et al. (2020). Preparing for Education 4.o: Skills Facing Economic, Social and Environmental Challenge. International Journal of Innovation, Management and Technology. 11(1): 275-279.

Meylinda Maria \& Faaizah Shahbodin. (2018). Malaysian Higher Education System Towards Industry 4.o - Current Trends Overview. https://www.researchgate.net/publication/327922991_Malaysian_higher_education _system_towards_industry_40_-_Current_trends_overview [8 March 2020].

Minister of Education. N.d. Kategori kurikulum program pengajian inovatif. https://www.moe.gov.my/en/muatturun/khas/akri/2018-1/kategori-kurikulum-program-pengajian-inovatif [8 March 2020].

Murphy, R. J., Gray, S. A., Straja, S. R., \& Bogert, M. C. (2004). Student learning preferences and teaching implications : educational methodologies. Journal of Dental Education, 68 (8): 859-866.

Nabiollah Sadeghi, Zalina Kasim, Bee Hoon Tan \& Faiz Sathi. (2012). Learning Styles, Personality Types and Reading Comprehension Performance. English Language Teaching, 5(4): 116-123.

Naseer Ahmad, Abid Ashar \& Syeda Amina. (2020). Association of Visual, Aural, Read/Write, and Kinesthetic (VARK) Learning Styles and Academic Performances of Dental Students. Pakistan Armed Forces Medical Journal, 7o(Suppl-1): 58-63.

Norasmah Othman \& Mohd Hasril. (2010). Different Perspectives of Learning Styles from VARK Model. In International Conference on Learner Diversity 2010. Procedia Social and Behavioral Sciences. pp. 652-66o

Oral, G. A. (2013). Generations in working life and conflicts. MA Diss., Bahcesehir University, Istanbul.

Piping, S. (2005). Penerapan teori multiple intelligence dalam pembelajaran. Jurnal Pendidikan Penabur, 4(5):2938.

Rania \& Esra. (2020). Future of Education in Industry 4.o: Educational Digitization - A Canadian Case Study. In Aysegul Ozbebek \& Pinar Aslan. 2020. Business Management and Communication Perspectives in Industry 4.o p 267-287. United States of America: ISI Global.

Schwab, K. (2016). The Fourth Industrial Revolution. Geneva: World Economic Forum. https://www.weforum.org/about/the-fourth-industrial-revolution-by-klaus-schwab [8 March 2020].

Schwab, K., \& Davis, N. (2018). Shaping the Fourth Industrial Revolution. Geneva: World Economic Forum. https://www.weforum.org/focus/shaping-the-fourth-industrial-revolution [8 March 2020].

Slusarczyk. (2018). Industry 4.0: How are we ready?. Polish Journal of Management Studies 17(1):232-248.

Sosik, J \& Zhu, W. (2020). Facing and Embracing the Fourth Industrial Revolution With Character. The Journal of Character \& Leadership Development. 7(1): 54-68.

Rozana Sani. (2018). Innovative teaching at universities. The Star, 16 January.

VARK. (2017). The VARK questionnaire: How do I learn best? VARK questionnaire version 7.1. VARK Learn Limited, Christchurch, New Zealand. http://vark-learn.com/the-vark-questionnaire/ [8 March 2020].

Wierzbicka Wioletta. (2018). Information Infrastructure as a Pillar of the Knowledge-based Economy-An Analysis of Regional Differentiation in Poland. Equilibrium. Quarterly Journal of Economics and Economic Policy. 13(1):123-139. 